\title{
Short Communication: Polymorphism at third exon of the Myostatin gene and its association with growth and carcass traits in Batur sheep
}

\author{
HASSAN ISHAG HASSAN HAREN ${ }^{1, \nu}$, DATTADEWI PURWANTINI ${ }^{2, \nu,}$, MAS YEDI SUMARYADI ${ }^{2, v \vee v}$ \\ PRAYITNO ${ }^{2, \text { rvY }}$ \\ ${ }^{1}$ Department of Animal Production, Faculty of Agriculture, Omdurman Islamic University. Fetahab st., Omdurman 283, Khartoum, Sudan. \\ Tel./fax. +68-2-223631145, `email: haren20101@gmail.com \\ ${ }^{2}$ Department of Animal Breeding, Faculty of Animal Science, Universitas Jenderal Soedirman. J1. Dr. Soeparno, Purwokerto Utara, Banyumas 53122, \\ Central Java, Indonesia. Tel.: +62-281-624792, 638792, "wemail: dattadewi2002@yahoo.com, ${ }^{\text {vw }}$ yedi.sumaryadi@yahoo.com, \\ vwrv prayitnofapet@gmail.com
}

Manuscript received: 13 February 2020. Revision accepted: 18 April 2020.

\begin{abstract}
Haren HIH, Purwantini D, Sumaryadi MY, Prayitno. 2020. Short Communication: Polymorphism at third exon of the Myostatin gene and its association with growth and carcass traits in Batur sheep. Biodiversitas 21: 2074-2078. The present study aimed to investigate the association between myostatin (MSTN) genotype and two traits, growth and carcass, in Batur sheep. Blood samples representing thirty head were collected and genomic DNA was extracted. A specific primer designed to amplify the MSTN gene, samples sequenced then, used the BioEdit program to identify any mutation. Calculation of genotypes, gene and allele frequencies, heterozygosities, and Chi-square test was performed. Only two alleles observed ( $\mathrm{G}$ and $\mathrm{C}$ ) resulted in three genotypes. 11 polymorphic sites were observed, transversion at $\mathrm{c} . * 121 \mathrm{G}>\mathrm{C}$, and one individual $\mathrm{G}>\mathrm{A}$ which disrupted reading frame of whole MSTN sequenced, genotypic and allelic frequencies were $0.552 \mathrm{GG}, 0.379 \mathrm{GC}$, and $0.069 \mathrm{CC}$, where the allele frequency was $0.741 \mathrm{G}$ and $0.259 \mathrm{C}$. Lambs that carrying genotype GC had slightly more pre-slaughter weight, hot carcass weight, cold carcass weight, carcass length, and total yield (lion, shoulder, leg yield, and thigh) compared to those carrying genotype GG. There was no significant effect of the MSTN genotype on carcass traits $(\mathrm{p}=0.05)$. Polymorphic site $\mathrm{c} *{ }^{*} 121 \mathrm{G}>\mathrm{C}$ is present in Batur sheep for the first time about the association with the MSTN gene however, it has not effects weaning weight, 6-month weight, and studied carcass traits.
\end{abstract}

Keywords: Batur sheep, carcass traits, growth traits, MSTN gene, third exon

\section{INTRODUCTION}

Myostatin which is also known as a growth and differentiation factor 8 (GDF8), acts as a negative regulator of skeletal muscle growth. Variation in the Myostatin gene (MSTN) has been associated with muscling in mammalian including mice (McPherron et al. 1997), cattle (Grobet et al. 1997; Dunner et al. 2003), humans (Schuelke et al. 2004), dogs (Mosher et al. 2007), and sheep (Kijas et al. 2007; Boman and Våge 2009; Johnson et al. 2009; Hickford et al. 2010; Han et al. 2013). The polymorphism of this gene has been determined in various breeds of sheep (Zhou et al. 2008) and goat (Han et al. 2015). The ovine MSTN gene is 4991bp in size and is present on chromosome no. 2 (Boman et al. 2009). Single Nucleotide Polymorphisms (SNPs) within the coding region of the Myostatin gene are associated with double muscling (Hadjipavlou et al. 2008). Moreover; the Myostatin sequence analysis of double-muscled European breed revealed 7 DNA sequence polymorphisms and concluded that five of them were responsible for modulating the functions of protein (Joulia-Ekaza and Cabello 2007). Different methods for determining carcass and body composition of domestic animals have been extensively studied because of their nutritional and economic importance (De Paula et al. 2013). However, some methods are limited to use in laboratory conditions, and others due to their expensive cost (Scholz et al. 2015). Carcass quality traits are important for predicting the final amount of saleable meat per animal. These traits are correlated with live weight, affecting sheep farmers' income. Live measures (weights at different stages; ultrasound images of muscle transversal area and fat thickness) and postmortem traits (carcass weight, length, and conformation; Knight et al. 2014; Ciappesoni et al. 2014) help to assess muscularity, fattening, and other carcass properties, and are usually included in genetic evaluation systems. Only three polymorphisms have been observed in the coding region of the ovine MSTN gene so far. One nonsynonymous singlenucleotide polymorphism (SNP) in the $34^{\text {th }}$ codon was identified in the New Zealand Romney sheep (Zhou et al. 2008). Moreover, a deletion of one base pair in the position of the $960^{\text {th }}$ nucleotide (c.960delG) was found in Norwegian White sheep (Boman et al 2009), whereas insertion of one base pair in the position of the 120th nucleotide was identified in the Norwegian Spælsau (Boman and Våge 2009). These two nucleotide variations, located in the coding region of the MSTN gene, resulted in nonfunctional protein formation (Boman et al. 2010). The present study was aimed to investigate the association 
between MSTN genotype, and growth traits, and carcass traits in Batur lambs.

\section{MATERIALS AND METHODS}

\section{Animals and Experimental Design}

Batur sheep are the predominant breed in the upland areas of Banjarnegara - Indonesia - where they are well adapted to the local cold and humid environment. This breed developed by crossing between local breeds (Fat and Thin Tailed Sheep) and imported breed (Merino) (Prayitno 2010). Thirty heads of Batur sheep used for this experiment, the number of lambs born for every birth of each ewe was recorded and the suckling program of the lambs lasted for three months ( $90^{\text {th }}$ day). Batur lambs were reared at the Batur area under an intensive feeding system until six months of age. All lambs were fed by concentrated feed consist of mixed feedstuff gave 3\% of their body weight. Bodyweight measured monthly after weaning to six months of age. Male lambs were slaughtered by the Islamic method at weights (ranged from 25 to $45 \mathrm{~kg}$ ). Then, the carcasses were split off into two identical longitudinal halves and sectioned into five regions (neck, shoulder, ribs, loin, and leg). Hot carcass weights were measured directly at slaughter, HCW is the weight in kilograms of the carcass components minus the pelt, head, and gut. Then, carcasses chilled under $-4 \mathrm{C}^{\circ}$ for 24 hours in the big refrigerator room by hanging them up. Cold carcass weight measured 24 hours after slaughtering, other carcass data including loin yield, leg yield, total yield, and shoulder yield. The total yield is the sum of the leg, loin and shoulder yield for any given carcass.

\section{DNA Extraction}

Blood samples $(3 \mathrm{ml})$ were collected from the jugular vein of each head of experimental lambs and put it into the vacutainer tubes contained EDTA $(10 \mathrm{~mL}$ EDTA spray dried). For DNA extraction $200 \mu$ l of whole blood samples were used and performed according to the manufacturer protocol (Genetika science). To amplify the exon 3 region of MSTN gene a specific primer designed using the Primer3 software from the NCBI website in (Table 1).

The concentration and purity of isolated DNA were measured using Nano-Drop 8000 Spectrophotometer (Thermo Scientific, Waltham, Massachusetts, USA) by Absorbance method. About $1.5 \mu \mathrm{l}$ isolated DNA for measuring the concentration and purity in each spectrophotometer well. The absorbance reading recorded at A260/A280 nm. Then, the DNA concentration ( $\mathrm{ng} / \mu \mathrm{l})$ and DNA purity A260/280 were calculated.

\section{Polymerase Chain Reaction Conditions}

Each $25 \mu \mathrm{l}$ PCR reaction contained $25 \mathrm{ng}$ of genomic DNA, $12.5 \mu \mathrm{l} 2 \mathrm{x}$ Reaction mix of each primer, and 1.0 units of Taq DNA polymerase as shown in table 2, The cycling protocol was 5 minutes at $95^{\circ} \mathrm{C}$ as an initial denaturation, 35 cycles of denaturing at $94^{\circ} \mathrm{C}$ for 45 seconds, annealing at 73.9 for 45 seconds, extending at $72^{\circ} \mathrm{C}$ for $40 \mathrm{~s}$, with final extension for 10 minutes.

\section{Coding region of MSTN sequencing}

All samples were sent to Malaysia for sequencing and the BioEdit program was used to identify a nucleotide substitution or mutation, and sequenced results compared with MSTN gene reference (accession number DQ530260) coding regions. The chromosome ovr2 of the MSTN region used to identify a candidate gene by the Ensembl database (www.ensembl.org). A candidate gene was chosen based on their known function or potential involvement with growth and muscularity.

\section{Data analysis}

Genotypes, and allele frequencies, heterozygosity rates were counted and Chi-square test was performed. The mathematical model for gene and allele frequency (Nei and Kumar 2000) as:

Genotype frequency $=\mathrm{Xi}=\frac{\mathrm{Gi}}{\mathrm{N}} \times 100 \%$

Allele frequency $=\mathrm{Xi}=\frac{2 \mathrm{nii}+2 \mathrm{nij}}{2 \mathrm{~N}}$

Where:

$\mathrm{Xi}=$ Genotype or allele frequency,

$\mathrm{i}^{\text {th }}=$ homozygous alleles,

$\mathrm{j}^{\text {th }}=$ heterozygous alleles,

$\mathrm{Gi}=$ number samples of $\mathrm{i}$ genotype

$\mathrm{N}=$ total samples.

Statistical analysis using ANOVA procedure (software SPSS program version 17.0) was utilized to determine the correlation between MSTN genotype and body weight and weaning weight.

Table 1. Primer forward and reverse for MSTN Amplification

\begin{tabular}{lllll}
\hline $\begin{array}{l}\text { Amplified } \\
\text { fragment }\end{array}$ & $\begin{array}{l}\text { Size } \\
(\mathbf{b p})\end{array}$ & $\begin{array}{l}\text { Primer } \\
\text { name }\end{array}$ & Primer sequence & $\begin{array}{l}\text { Tm } \\
\left({ }^{\circ} \mathbf{C}\right)\end{array}$ \\
\hline MSTN & 487 & Forward & $5^{\prime}{ }^{-}$ & 61.2 \\
& & $:$ & $\begin{array}{l}\text { TGCGGTAGGAGA } \\
\text { GTGTTTGG-3' }\end{array}$ & \\
& & Reverse: & $5^{\prime}{ }^{\prime}-$ \\
& & & AAAATTGTTGAGG & \\
& & & GGAAGACC-3' & \\
\hline
\end{tabular}

Table 2. PCR reaction mixture for amplification of MSTN gene of sheep

\begin{tabular}{ll}
\hline Reaction components & Quantity $(\boldsymbol{\mu L})$ \\
\hline Kapa mix & 12.5 \\
Forward primer & 1.0 \\
Reverse primer & 1.0 \\
DNA template & 1.0 \\
dH2O & 9.5 \\
Total & 25 \\
\hline
\end{tabular}




\section{RESULTS AND DISCUSSION}

\section{MSTN Genotyping}

A $487 \mathrm{bp}$ fragment for the $3^{\text {rd }}$ exon of MSTN locus in Batur sheep was proliferated by manual PCR technique. The analysis revealed a total of seventeen polymorphic sites in the MSTN coding region (Figure 1). There were only two observed alleles ( $G$ and $C$ ) resulting in three genotypes, the animals with both alleles were considered as GC genotype, whereas those possessed only $\mathrm{G}$ or $\mathrm{C}$ alleles assigned as GG or CC genotypes. Eleven polymorphic sites were observed in the $3^{\text {rd }}$ exon region, transversions at locus c.*121 G>C , one individual G>A which disrupted the reading frame in whole MSTN sequenced, and one individual polymorphic sites seen a del-T at c.*129, c.*139 and c.*158 positions as in the figure. In an investigated population, this locus was in Hardy-Weinberg equilibrium with $\mathrm{X}^{2}$ test of 0.0034 and probability of $(\mathrm{p}=0.95)$. This confirmed that factors leading to disequilibrium, especially selection and migration, may affect the genetic structure of the population. The studied population showed a low degree of genotypic variability for the MSTN gene. This may be explained by the conservation and no breeding plans have been applied, because there are many rams that have been used randomly as sires in a breeding system which is a result of the inbreeding effect. As previously reported by the authors (Haren et al. 2019) the high similarity of the MSTN gene in Batur sheep observed because of their coding region are similar, a genetic variation found at the $3^{\mathrm{rd}}$ exon region may not influence mRNA splicing and therefore affect the amino acid sequences produced from a process of the transcription.
Moreover, a breed-specific influence of the locus under study.

\section{Effect of MSTN genotype on growth traits}

Table 3 indicates that genotypic and allele frequencies in the $3^{\text {rd }}$ exon of Myostatin genotype were $0.552(\mathrm{GG})$, $0.379(\mathrm{GC})$, and $0.069(\mathrm{CC})$, where the allele frequency was $0.74 \mathrm{G}$ and $0.26 \mathrm{C}$, however; weaning weight of Batur lambs were 19.99 GG, 21.3 GC, and 19.7 CC and 6-month weight 30.49 (GG), 31.87 (GC), and 29.9 (CC), respectively. Lambs with heterozygous (GC) genotype were heavier than homozygous (GG) and recessive (CC) genotype by 1.6 and $2 \mathrm{~kg}$ at weaning and 6-months weight, respectively. However, there was no significant difference at weaning weight $(\mathrm{p}=0.99)$, 6-month body weights $(p=0.98)$ at a locus $\left(c *^{*} 121 \mathrm{G}>\mathrm{C}\right)$ of the MSTN gene in Batur sheep. Similar findings for the non-significant effect of genetic variants in exon 3 of the MSTN gene with growth traits were reported in Zel sheep (Dehnavi et al. 2012).

\section{Effect of MSTN genotype on carcass traits}

The carcass traits and their proportion yield are present in Table 4, lambs that carry the GC genotype have slightly more pre-slaughter weight, hot carcass weight, cold carcass weight, carcass length and total yield (loin, shoulder, leg yield, and rump) comparing to those carry's the GG genotype. The results showed there was no significant effect of the MSTN genotype on carcass traits $(P>0.05)$. It might be due to the increase in muscle mass.

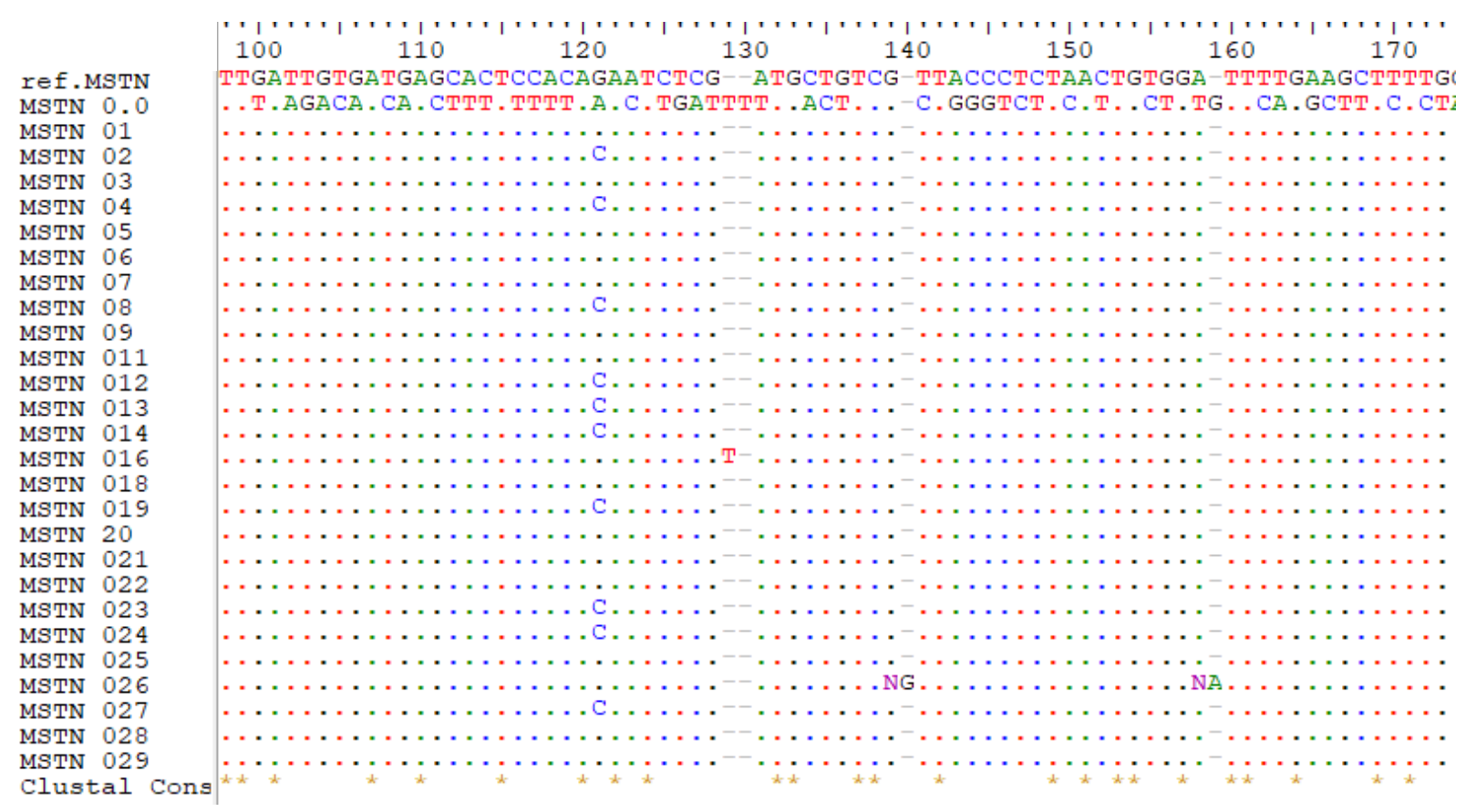

Figure 1. Chromatogram of BioEdit program used to identify if any nucleotide substitution in the $3^{\text {rd }}$ exon of MSTN gene, all sequence plotted to a standard as a dot, compared to the reference sequence (NCBI) there are 17 different variants on the matched sequence 
positions, 11 variants appeared at c.*121, del-T at c.*129, one individual at c.*139, and one individual at c. $* 158$ positions, however, one individual sequence disrupted reading frame in MSTN

Table 3. Genotypic, allelic frequencies and heterozygosity of exon 3 of locus c.*121G $>\mathrm{C}$ and its association with weaning and body weight in Batur sheep

\begin{tabular}{|c|c|c|c|c|c|c|c|}
\hline Genotype & (16) GG & (11) GC & (2) $\mathrm{CC}$ & G & $\mathbf{C}$ & $\mathbf{X}^{2}$ & p-value \\
\hline Genotypic frequency & 0.552 & 0.379 & 0.069 & 0.74 & 0.26 & & - \\
\hline Expected frequency & 0.549 & 0.384 & 0.067 & & & 0.0034 & 0.95 \\
\hline Weaning & $19.99 \pm 1.3$ & $21.3 \pm 1.5$ & $19.7 \pm 4.5$ & & & & 0.99 \\
\hline 6-month weight & $30.49 \pm 1.6$ & $31.9 \pm 1.9$ & $29.9 \pm 1.8$ & & & & 0.98 \\
\hline
\end{tabular}

Table 4. Means, standard deviation (S.D), minimum and maximum weights $(\mathrm{kg}$ ) for carcass traits

\begin{tabular}{|c|c|c|c|c|c|c|c|c|c|}
\hline & \multicolumn{4}{|c|}{ Genotype GG } & \multicolumn{4}{|c|}{ Genotype GC } & \multirow[b]{2}{*}{$\mathrm{p}$-value } \\
\hline & Mean & S. D & Min & Max & Mean & S. D & Min & $\operatorname{Max}$ & \\
\hline PSW (kg) & 32.7 & 2.8 & 30.7 & 34.7 & 34.3 & 2.85 & 31 & 36.3 & 0.59 \\
\hline $\mathrm{HCW}(\mathrm{kg})$ & 13.4 & 0.0 & 13.4 & 13.4 & 14.6 & 1.55 & 13.1 & 16.2 & 0.38 \\
\hline CCW (kg) & 13.3 & 0.07 & 13.2 & 13.3 & 14.4 & 1.50 & 13 & 16 & 0.37 \\
\hline Carcass length $(\mathrm{cm})$ & 75 & 0.0 & 75.0 & 75.0 & 78.0 & 3.46 & 74 & 80 & 0.33 \\
\hline Total yield (kg) & 8.05 & 0.07 & 8.00 & 8.10 & 8.10 & 1.49 & 6.4 & 9.2 & 0.97 \\
\hline Lean yield $(\mathrm{kg})$ & 7.4 & 0.85 & 6.80 & 8.00 & 8.87 & 0.95 & 7.8 & 9.6 & 0.18 \\
\hline Bone yield (kg) & 3.6 & 0.28 & 3.40 & 3.80 & 3.87 & 1.03 & 3.0 & 5.0 & 0.58 \\
\hline Fat yield $(\mathrm{kg})$ & 2.1 & 0.14 & 2.00 & 2.20 & 2.07 & 0.61 & 1.4 & 2.6 & 0.95 \\
\hline Dressing \% & 41 & 0.04 & 39 & 44 & 43 & 0.03 & 40 & 46 & 0.64 \\
\hline Boneless \% & 56 & 0.07 & 51 & 61 & 61 & 0.025 & 60 & 64 & 0.26 \\
\hline
\end{tabular}

Note: $\mathrm{HCW}=$ hot carcass weights, CCW = cold carcass weight, PSW = Pre-slaughter weight

\section{Discussion}

The inability to find any association of weaning and body weight with the polymorphic status of the MSTN gene in the present study might be due to the breed-specific effect of the locus under study. This study in line with (Sahu et al. 2017) which mentioned that, a non-significant effect of this mutation that observed on birth, weaning (three months) and six months weight in Indian Mecheri and Madras Red sheep. (Sumantri et al. 2008) reported that genetic diversity based on molecular marker MSTN c.del960G locus in Indonesia local sheep are very low. This is indicated by the value of one genotype frequency and allele which has a value of 1 , which marks the fixation process. The absence of deletion in 1-bp deletion at MSTN c.del $960 \mathrm{G}$ can be caused by a tropical adaptation process which suggested that the animal which can survive in this environment is having small performance. In this case, presence of the c.960delG mutation in both alleles means that no functional Myostatin protein is expected to be produced (Boman et al. 2009).

If Myostatin did not express, so the negative growth regulation will fail and the number of muscle fibers increases (hyperplasia). (Boman et al. 2010) reported the homozygous c.960delG (AA) animals had lower daily gain and weaning weight, but higher carcass weight. While the genotypes (del-G)-AG and (del-G)-GG resulted in significant $(p<0.001)$ effects, towards more meat and less fatty animals. However, mutations in the third exon affect conformation and fat class in NWS lambs, yielding a carcass with less fat and increased muscle mass these findings are not far to our study concerning fat, muscles, and carcass yield.
In conclusion, the present study investigated the allelic and genotypic effects of the MSTN gene on growth and carcass traits, polymorphism is present in Batur sheep for the first-time regarding assessment of the association with the $3^{\text {rd }}$ exon of the MSTN gene. Moreover, non-significant genotypic effects of the MSTN gene have detected concerning weaning weight, 6-month weight, and studied carcass traits. Moreover, these results may not be useful for developing future selection programs unless further investigation of the MSTN gene and it is interaction performed with other genes that involve in muscle growth and carcass traits through analyzing association studies at large scale.

\section{ACKNOWLEDGEMENTS}

This research has been supported by Jenderal Soedirman University Program (Riset Institusi Unsoed No. P/495/UN23/14/PN/2019), Purwokerto, Indonesia.

\section{REFERENCES}

Boman IA, Klemetsdal G, Blichfeldt T, Nafstad, Våge DI. 2009. A frameshift mutation in the coding region of the Myostatin gene (MSTN) affects carcass conformation and fatness in Norwegian White Sheep (Ovis Aries). Anim Genet 40: 418-422. DOI: 10.1111/j.1365-2052.2009.01855.x.

Boman I, Våge D. 2009. An insertion in the coding region of the Myostatin (MSTN) gene affects carcass conformation and fatness in the Norwegian Spælsau (Ovis aries). BMC Res Notes 2 (1): 98. DOI: 10.1186/1756-0500-2-98. 
Boman I, Klemetsdal G, Nafstad O, Blichfeldt T, Våge D. 2010. Impact of two Myostatin (MSTN) mutations on weight gain and lamb carcass classification in Norwegian White Sheep (Ovis aries). Genet Sel Evol 42 (1): DOI: 10.1186/1297-9686-42-4.

Ciappesoni G, San Julián R, Navajas E, Gimeno D, Gutierrez-Zamit E, Goldberg V, Brito G. 2014. Genetic evaluation of the Texel breed in Uruguay, Carcass quality traits. 60th International Congress of Meat Science and Technology, 17-22 August 2014. Punta del Este.

Dehnavi E, Azari MA, Hasani S, Nassiry MR, Mohajer M, Ahmadi AK, Shahmohamadi L, Yousefi S. 2012. Polymorphism of Myostatin gene in Intron 1 and 2 and Exon 3, and their associations with yearling weight, using PCR-RFLP and PCR-SSCP techniques in Zel sheep. Biotechnol Res Int. DOI: 10.1155/2012/472307.

De Paula NF, Tedeschi LO, Paulino MF, Fernandes HJ, Fonseca MA 2013. Predicting carcass and body fat composition using biometric measurements of grazing beef cattle. J Anim Sci 91: 3341-3351. DOI: $10.2527 /$ jas.2012-5233

Dunner S, Miranda ME, Amigues Y, Canón J, Georges M, Hanset R, Williams JL, Ménissier F. 2003. Haplotype diversity of the Myostatin gene among beef cattle breeds. Genet Sel Evol 35: 103-118. DOI 10.1186/1297-9686-35-1-103.

Grobet L, Martin LJR, Poncelet D, Pirottin D, Brouwers B, Riquet J, Schoeberlein A, Dunner S, Menissier F, Massabanda J Fries R, Hanset R, Georges M. 1997. A deletion in the bovine Myostatin gene causes the double-muscled phenotype in cattle. Nat Genet 17: 71-74 DOI: $10.1038 / n g 0997-71$.

Hadjipavlou G, Matika O, Clop A, Bishop S. 2008. Two single nucleotide polymorphisms in the Myostatin (GDF8) gene have significant association with muscle depth of commercial Charollais sheep. Anim Genet 39 (4): 346-353. DOI: 10.1111/j.1365-2052.2008.01734.x.

Han J, Forrest RH, Hickford JGH. 2013. Genetic variations in the Myostatin gene (MSTN) in New Zealand sheep breeds. Mol Biol Rep 40 (11): 6379-6384. DOI: $10.1007 / \mathrm{s} 11033-013-2752-7$.

Han J, Forrest R H, Sedcole J R, Hickford J G H. 2015. Myostatin (MSTN) gene haplotypes and their association with growth and carcass traits in New Zealand Romney lambs. Small Ruminant Res 127: 8-19. DOI: 10.1016/j.smallrumres.2015.03.015.

Haren HIH, Purwantini D, Sumaryadi MY, Prayitno. 2019. Polymorphism of Myostatin Gene (MSTN) Coding Region in Batur Sheep. Anim Prod 21 (1): 10-15.

Hickford JGH, Forrest RH, Zhou H, Fang Q, Han J, Frampton CM, Horrell AL. 2010. Polymorphisms in the ovine Myostatin gene (MSTN) and their association with growth and carcass traits in New Zealand Romney sheep. Anim Genet 41: 64-72. DOI: 10.1111/j.13652052.2009.01965.x.

Johnson PL, Dodds KG, Bain WE, Greer GJ, McLean NJ, McLaren RJ, Galloway SM, van Stijn TC, McEwan JC. 2009. Investigations into the GDF8 g+6273G-A polymorphism in New Zealand Texel sheep. $\mathrm{J}$ Anim Sci 87: 1856-1864. DOI: 10.2527/jas.2008-1508.

Joulia-Ekaza D, Cabello G. 2007. The Myostatin gene physiology and pharmacological relevance. Curr Opin Pharmacol 7 (3): 310-315. DOI: 10.1016/j.coph.2006.11.011.

Kijas JW, McCulloch R, Edward JEH, Oddy VH, Lee SH, Van der Werf J. 2007. Evidence for multiple alleles effecting muscling and fatness at the ovine GDF8 locus. BMC Genet 8 (1): 80. DOI: 10.1186/14712156-8-80.

Knight MI, Daetwyler HD, Hayes BJ, Hayden MJ, Ball AJ, Pethick DW, McDonagh MB. 2014. An independent validation association study of carcass quality, shear force, intramuscular fat percentage and omega-3 polyunsaturated fatty acid content with gene markers in Australian lamb. Meat Sci 96: 1025-1033. DOI: 10.1016/j.meatsci.2013.07.008.

McPherron AC, Lawler AM, Lee SJ. 1997. Regulation of skeletal muscle mass in mice by a new TGF- superfamily member. Nature 387: 8390. DOI: $10.1038 / 387083 \mathrm{a} 0$.

Mosher DS, Quignon P, Bustamante CD, Sutter NB, Mellersh CS, Parker HG, Ostrander EA. 2007. A mutation in the Myostatin gene increases muscle mass and enhances racing performance in heterozygote dogs. PLoS Genet 3 (5): 779-786. DOI: 10.1371/journal.pgen.0030079.

Nei Mn, Kumar S. 2000. Molecular evaluation and phylogenetics. Oxford Univ Press, New York.

Prayitno. 2010. Analisis Genetik dan Kekerabatan Domba Batur dengan Domba Lokal dan Merino Menggunakan Marker RAP-DNA. Laporan Penelitian Hibah Doktor. Universitas Gadjah Mada, Yogyakarta. [Indonesian]

Sahu A, Jeichitra V, Rajendran R, Raja A. 2017. Polymorphism in exon 3 of Myostatin (MSTN) gene and its association with growth traits in Indian sheep breeds. Small Ruminant Res149: 81-84. DOI: 10.1016/j.smallrumres.2017.01.009.

Scholz AM, Bünger L, Kongsro J, Baulain U, Mitchell AD. 2015. Noninvasive methods for the determination of body and carcass composition in livestock: dual-energy X-ray absorptiometry, computed tomography, magnetic resonance imaging, and ultrasound: invited review. Animal 9:1250-1264. DOI: 10.1017/s1751731115000336.

Schuelke M, Wagner KR, Stolz LE, Hübner C, Riebel T, Kömen W, Lee SJ. 2004. Myostatin mutation associated with gross muscle hypertrophy in a child. New England J Med 350 (26): 2682-2688. DOI:10.1056/nejm200409023511018.

Sumantri CR, Diyono A, Farajallah, Inounu I. 2008. Polymorphism of calpastatin gene and its effect on body weight of local sheep's. JITV 13: 117-126.

Zhou H, Hickford JGH, Fang Q. 2008. Variation in the coding region of the Myostatin (GDF8) gene in sheep. Mol Cellular Probes 22: 67- 68. DOI: $10.1016 /$ j.mcp.2007.08.004. 